\title{
PAНHEЕ ОБНАРУЖЕНИЕ ВИРУСОВ И БАКТЕРИЙ С ИСПОЛЬЗОВАНИЕМ МЕТОДОВ НАНОТЕХНОЛОГИЙ
} EARLY DETECTION OF VIRUSES AND BACTERIA
USING METHODS OF NANOTECHNOLOGY

УДК 543.07, ВАК 05.11.13, DOI:10.22184/1993-8578.2017.71.1.70.74

\author{
А.Ахметова 1,2 , И.Яминский 1,2 / yaminsky@nanoscopy.ru \\ A.Akhmetova' ${ }^{1,2}$, I.Yaminsky', 2
}

\begin{abstract}
Современные нанотехнологии открывают новые эффективные пути раннего обнаружения вирусных и бактериальных инфекций. В настоящей работе представлены два родственных метода, основанных на применении сканирующих зондовых микроскопов и пьезокерамических биочипов. Использование в обоих случаях герметичных проточных жидкостных ячеек позволяет проводить измерения безопасным для обслуживающего лаборанта способом и с чувствительностью на уровне от единиц до сотен патогенов в миллилитре.

Modern nanotechnology opens up new effective ways of early detection of viral and bacterial infections. This paper presents two related methods based on the use of scanning probe microscopes and piezoelectric biochips. Use of a sealed flow-through liquid cell in both cases allows safe measurements with sensitivity from units to hundreds of pathogens in a milliliter.
\end{abstract}

$\Pi$ ри возникновении инфекционного вирусного или бактериального заболевания ответственной задачей является обнаружение конкретного возбудителя. Еще важнее выявление вируса в окружающей среде, пока он не поразил растение, животное или человека. Этой цели и посвящен наш проект "Разработка сенсорных технологий молекулярной диагностики для персонифицированной медицины".

Современная персонифицированная медицина в большой степени направлена на предупреждение болезни, чтобы избежать как заболевания, так и его возможных последствий. Развитие науки и технологий позволяет создавать новые эффективные меры предупреждения и лечения инфекций. Однако и здесь возникают существенные осложнения из-за возвращения старых и возникновения новых инфекционных заболеваний, которые становятся серьезным вызовом современной медицине. Многие ученые активно участвуют в решении этих проблем.

По итогам 2016 года журнал Science определил 10 самых прорывных открытий года. В их число вошла работа доктора Дэвида Бейкера (David Baker), профес- сора биохимии из университета штата Вашингтон. Вместе со своей командой он научился моделировать белки и предсказывать процесс формирования их пространственных структур. Например, он смог определить, как синтезированные белки, изменяя свою конфигурацию, будут образовывать пространственные структуры. Это открытие дает импульс созданию вакцины от гриппа нового поколения. Вирусы гриппа мутируют достаточно быстро, что делает разработку эффективного для всех штаммов препарата трудновыполнимой. Но каждый штамм гриппа содержит белок гемагглютинин, который помогает ему вторгнуться в клетку-хозяина. Часть молекулы гемагглютинина, состоящая из $\alpha$-спиралей, одинакова во многих штаммах. Д.Бейкер разработал новый белок, который связывается с неизменяющейся частью гемагглютинина, тем самым предотвращается вторжение вируса в клетку. В 2016 году были опубликованы результаты эксперимента с мышами, которым сначала ввели новый белок, а затем смертельную дозу вируса гриппа. В итоге экспериментов было показано, что грызуны были защищены от вируса [1]. 


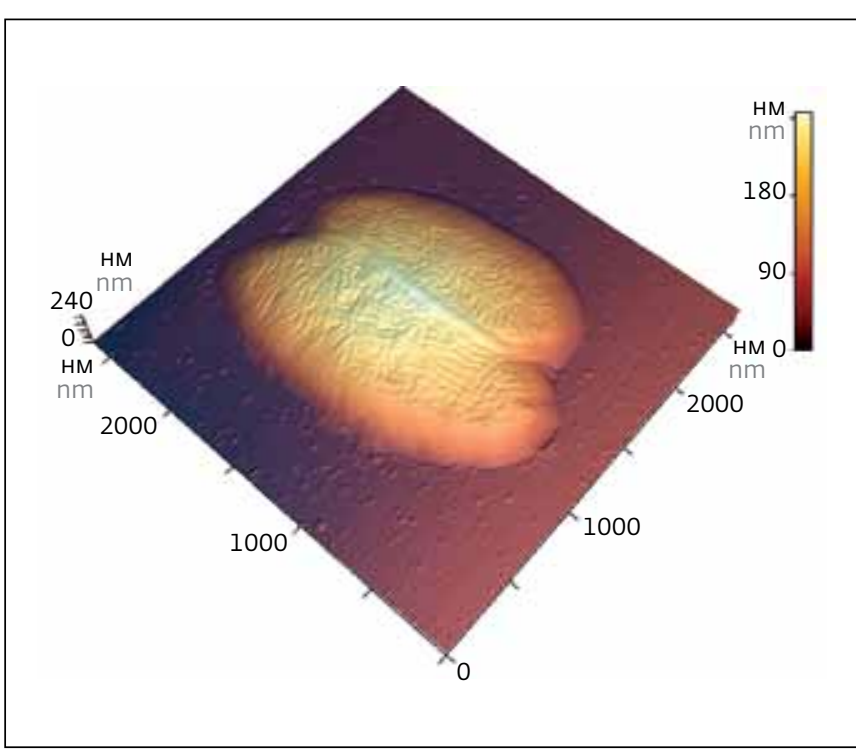

Рис.1. Изображение бактериальных киеток на поверхности биочипа, полученное методом сканирующей зондовой микроскопии с применением программного обеспечения "ФемтоСкан Онлайн" [2]

Fig.1. Image of bacterial cells on surface of biochip obtained by scanning probe microscopy using Femtoscan Online software [2]

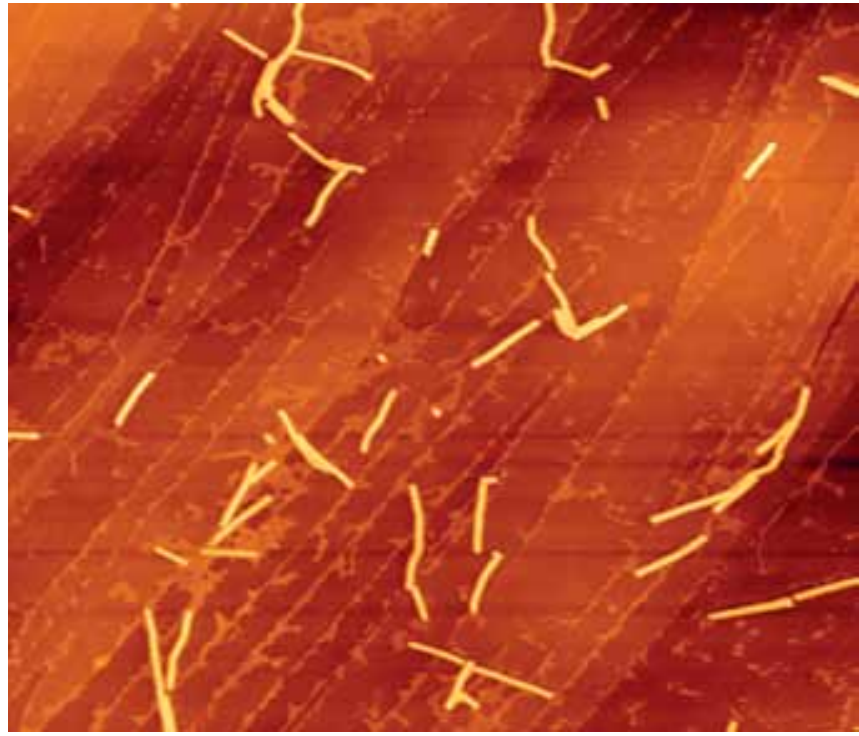

Puс. 2. Изображение вируса табачной мозаики, полученное методом сканирующей зондовой микроскопии с применением программного обеспечения "ФемтоСкан Онлайн". Наблюдаемые размеры вируса: длина 300 нм, высота 17 нм Fig.2. Image of tobacco mosaic virus obtained by scanning probe microscopy using FemtoScan Online software. Sizes of virus: length of $300 \mathrm{~nm}$ and height of $17 \mathrm{~nm}$
$\mathbf{T}$ he detection of the causative agent of an infectious viral or bacterial diseases is a demanding task. Even more important is the detection of the virus in the environment until it struck the plant, animal or human. Our project "Development of sensor technologies for molecular diagnostics for personalized medicine" is dedicated to this purpose.

Modern personalized medicine is largely focused on disease prevention to avoid disease and its possible consequences. The development of science and technologies allows to create a new effective measures for prevention and treatment of infections. However, there are significant difficulties due to the return of the old and emergence of new infectious diseases that are a serious challenge to modern medicine. Many scientists are actively involved in solving these problems.
The Science journal has identified 10 of the most groundbreaking technologies of 2016 . Among them is the work of David Baker, Professor of biochemistry at the University of Washington. Together with his team, he learned how to model proteins and predict the formation of their spatial structures. For example, he was able to determine how the synthesized proteins, changing their configuration, will form a spatial structure. This discovery gave impetus to the creation of flu vaccines of the new generation. Flu viruses mutate fairly quickly, which makes difficult the development of a drug that would be effective for all strains. But each strain of influenza contains the hemagglutinin protein that helps it invade a host cell. Part of the hemagglutinin molecule, consisting of $\alpha$-helices, is identical in many strains. D.Baker has developed a new protein that binds to the unchanging part of hemagglutinin, thereby preventing the invasion of the virus into the cell. The results of the experiment with the mice with introduction of a new protein and a lethal dose of influenza virus were published in 2016. As a result of experiments, it was shown that rodents were protected from the virus [1].

Scanning probe microscopy allows to detect both bacterial cells (Fig.1) and individual viral particles (Fig.2). Fig.2 shows particles of tobacco mosaic virus, which is actively used for virological research and educational purposes in laboratory workshops [2].

To identify viruses, we investigate the ability of hemagglutinin to attach to the cells. In the framework of the project "Development of sensor technologies for molecular diagnostics for personalized 


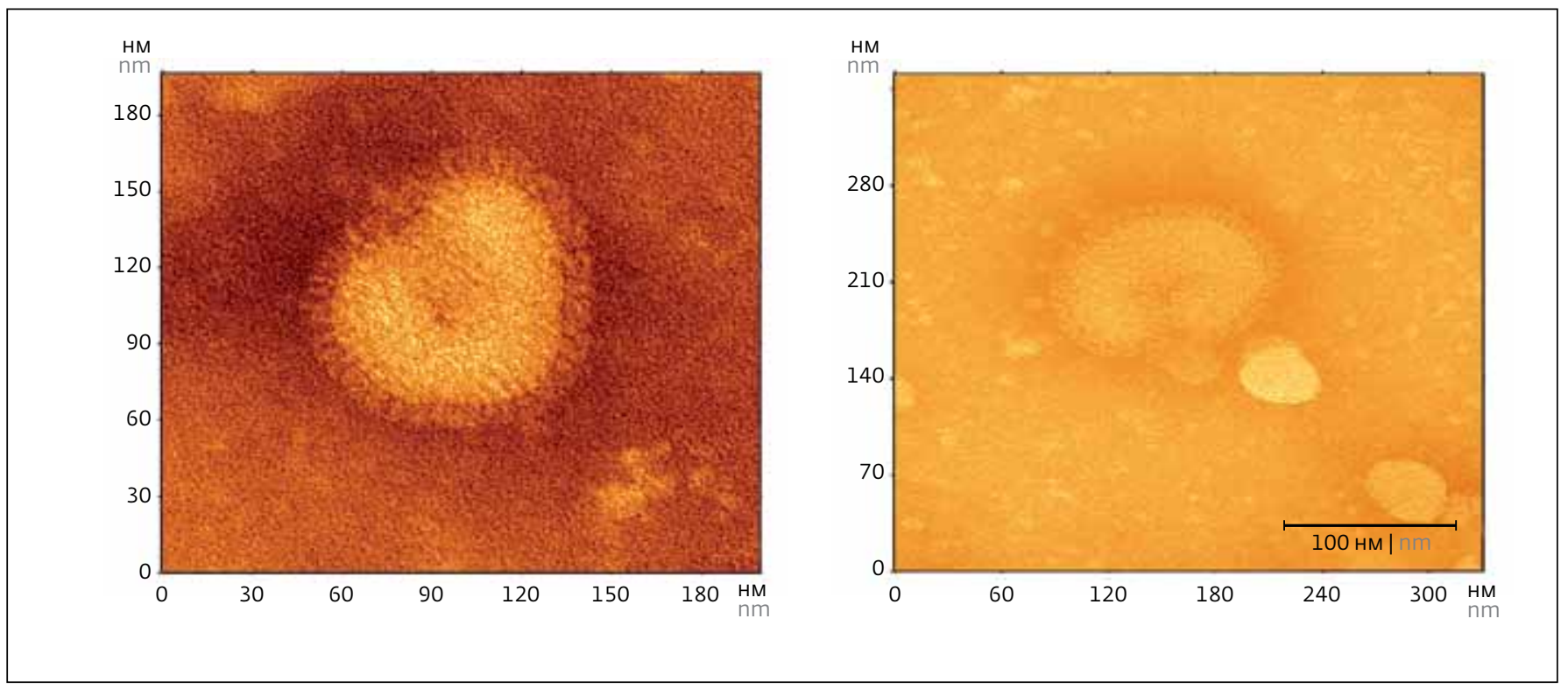

Puc.3. Изображение вирусов грипnа H4NG (слева) и H3NG (справа), полученное на просвечивающем электронном микроскопе LEO912AB (контрастирование фосфорно-вольфрамовой кислотой) с применением программного обеспечения "ФемтоСкан Ониайн" Fig.3. Image of H4NG (at left) and H3NG (at right) influenza virus obtained on transmission electron microscope LEO912AB (contrasting by tungstophosphoric acid) with use of FemtoScan Online software

Сканирующая зондовая микроскопия позволяет обнаруживать как бактериальные клетки (рис.1), так и отдельные вирусные частицы. На рис.2 изображены частицы вируса табачной мозаики, который активно применяют как для вирусологических исследований, так и в образовательных целях в лабораторных практику$\max [2]$.
С целью выявления вирусов мы исследуем способность гемагглютинина прикрепляться к клеткам. В рамках проекта "Разработка сенсорных технологий молекулярной диагностики для персонифицированной медицины" создаются два прибора для обнаружения вируса гриппа А и бактерий E.coli: усовершенствованный сканирующий зондовый микроскоп "ФемтоСкан" и биосенсор на основе пье- medicine " we develop two devices for detection of influenza A virus and E.coli bacteria: an advanced scanning probe microscope "FemtoScan" and the biosensor based on piezoelectric cantilevers. Both devices use a special biochip on the basis of a piezoceramic disk, the electrodes of which are covered by a sensory layer. For detection of influenza virus sensory layer of the biochip contains polysaccharides with sialic acids, providing biospecifically binding to hemagglutinin of the virus. In case of detection of bacterial cells, the antibodies against surface antigenic determinants of the cells are placed on the surface of the sensory layer. Details of the design and the working principle of biosensor and microscope are described in previous publications [3-5]. Detection of biological agents in the biosensor is carried out by registration of the amplitude, phase, frequency and the quality factor of the mechanical vibrations of the biochip. In a probe microscope, in addition to the determination of these parameters, you can carry out the direct calculation of the number of pathogens on the surface of the biochip.

In 2016, to create a workable prototype of the biosensor we have developed the following key elements:
- flow-through liquid cell of biosensor in which the biochip is placed and the sample is circulated;

- control unit of the biosensor, which detects the vibrations of the biochip and provides the transfer of this information to the computer;

- package for the biosensor with cell and biochip;

- holder of a cantilever for flowthrough liquid cell.

Electronic measuring system and software are essential. As the last, the multiuser management platform of the FemtoScan scanning probe microscope is chosen. The software allows to determine the 
зокерамических кантилеверов. В обоих приборах используется специальный биочип на основе пьезокерамического диска, электроды которого покрыты сенсорным слоем. Для обнаружения вируса гриппа сенсорный слой биочипа содержит полисахариды с сиаловыми кислотами, обеспечивающими биоспецифическое связывание с гемагглютинином вируса. При обнаружении бактериальных клеток на поверхности сенсорного слоя располагаются антитела на поверхностные антигенные детерминанты клеток. Подробно о конструкции и принципе работы биосенсора и микроскопа рассказывалось в предыдущих публикациях [3-5]. В биосенсоре обнаружение биологических агентов осуществляется путем регистрации амплитуды, фазы, частоты и добротности механических колебаний биочипа. В зондовом микроскопе, помимо определения перечисленных параметров, можно проводить прямой подсчет на получаемых изображениях числа патогенов на поверхности биочипа.

Для создания работоспособной модели биосенсора в 2016 году нами были разработаны следующие ключевые элементы:

- проточная жидкостная ячейка биосенсора, в которой находится биочип и циркулирует проба;

- блок управления биосенсора, регистрирующий колебания биочипа и обеспечивающий передачу этой информации на компьютер;

- корпус биосенсора, в котором располагается ячейка с биочипом;

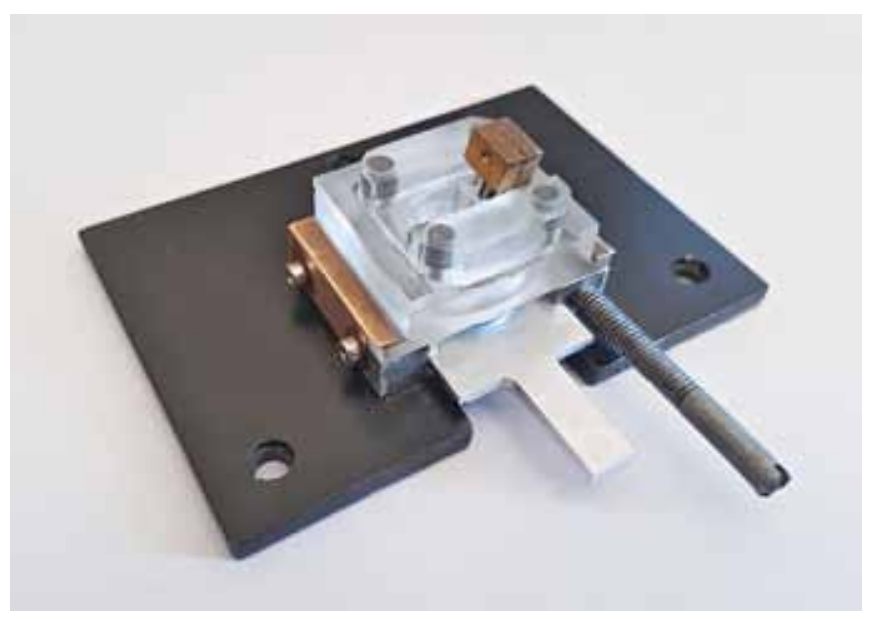

Рис.4. Общий вид макета проточной жидкостной ячейки для сканирующего зондового микроскопа "ФемтоСкан"

Fig.4. General view of model of flow-through liquid cell for Femtoscan scanning probe microscope

- держатель кантилевера для проточной жидкостной ячейки.

Существенное значение имеют электронная измерительная система и программное обеспечение. В качестве последнего выбрана многопользовательская платформа управления сканирующим зондовым микроскопом "ФемтоСкан". Программное обеспечение позволяет осуществлять поиск резонанса биочипа, определять значение его резонансной частоты. Наиболее чувствительным и помехозащи щенным способом определения резонансной resonant frequency of biochip. The most sensitive and noise-resistant method of determining the resonant frequency, as was shown earlier, is the method of "center of mass" [6].

In the experiments we use H3N6 and H4N6 influenza virus weakened by formaldehyde, which was provided by the Chumakov Federal Scientific Center for Research and Development of Immune-andBiological Products of RAS. Images of H3N6 and H4N6 influenza virus strains are shown in Fig. 3.

The models of the sealed flowthrough liquid cell (Fig.4) and of the head for resonance atomic force microscopy were created for the advanced scanning probe microscope. The design of the cell allows to install it in the microscope, and remove from the microscope in the assembled state without seal failure. This design is applied for the patents $[7,8]$. Flowthrough liquid cell can be designed for single use only. In any case, the biological entities -viruses and bacteria are in a closed isolated space during the measurement in scanning probe microscope.

The results of the first year of joint development of Lomonosov MSU and Advanced Technologies Center were presented at the VUZPROMEXPO exhibition, which was held on 14-15 December 2016. We have demonstrated the model of the biosensor including control unit and a package in which a flow-through liquid cell with the biochip are located, and the model of the advanced scanning probe microscope with a sealed flow-through liquid cell (Fig.5).

The study was performed with financial support of RFBR (research project No. 15-04-07678) and Ministry of education and science under contract No.02.G25.31.0135. The authors are grateful to D.Sc., head of the laboratory of molecular biology of influenza viruses at Chumakov Federal Scientific Center for Research and Development of Immuneand-Biological Products of RAS, Alexandra S. Gambaryan, for discussion and help. 
частоты, как было показано ранее, является метод "центра масс" [6].

В экспериментах мы используем ослабленный формальдегидом вирус гриппа H3N6 и H4N6, предоставленный Институтом полиомиелита вирусных энцефалитов им. М.П.Чумакова. Изображения вирусов гриппа штаммов H4N6 и H3N6 представлены на рис.3.

Для усовершенствованного сканирующего зондового микроскопа были созданы макет герметичной проточной жидкостной ячейки (рис.4) и макет головки резонансной атомно-силовой микроскопии (РАСМ). Конструкция ячейки позволяет устанавливать ее в микроскоп, а также вынимать из микроскопа в собранном состоянии без нарушения герметичности. На эту конструкцию поданы заявки на получение патентов $[7,8]$. Проточная жидкостная ячейка может быть выполнена для одноразового использования. В любом случае при измерениях на сканирующем зондовом микроскопе биологические объекты - вирусы и бактерии - находятся в замкнутом изолированном пространстве.

Итоги первого года совместной разработки МГУ им. М.В.Ломоносова и НПП "Центр перспективных технологий" были представлены на выставке ВУЗПРОМЭКСПО 14-15 декабря 2016 года. На выставке были продемонстрированы: макет биосенсора - блок управления и корпус, в котором расположена проточная жидкостная ячейка с биочипом, а также макет усовершенствованного сканирующего зондового микроскопа с герметичной проточной жидкостной ячейкой (рис.5).

Исследование выполнено при финансовой поддержке РФФИ в рамках научного проекта № 15-04-07678 и Минобрнауки России в рамках договора № 02.G25.31.0135. Авторы благодарны за дискуссию и помощь в работе доктору биологических наук, зав. лабораторией молекулярной биологии вирусов гриппа ФГБНу "Федеральный научный центр исследований и разработки иммунобиологических препаратов им. М.П.Чумакова РАН" Александре Сергеевне Гамбарян.

\section{ЛИТЕРАТУРА}

1. Robert F. Service. Rules of the game // Science. 22 Jul 2016. Vol. 353. Is. 6297. P. 338-341. DOI: 10.1126/science.353.6297.338.

2. Дубровин Е., Мешков Г., Яминский И. Наблюдение вируса табачной мозаики в практикуме сканирующей зондовой микроскопии // Наноиндустрия. 2014. № 2 (48). С. 46-52.

3. Колесов Д., Яминский И., Ахметова А., Синицына О., Мешков Г. Кантилеверные биосен-

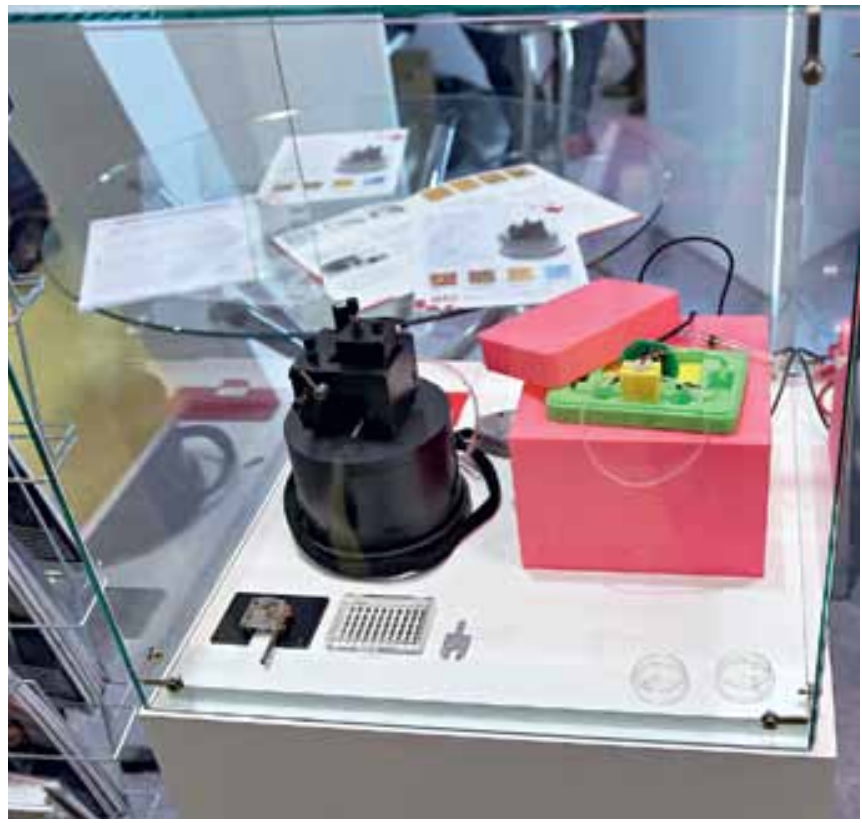

Pис.5. Макеты усовершенствованного сканирующего зондового микроскопа (слева) и биосенсора для диагностики вируса грunna A и бактерuи E.coli (справа)

Fig.5. Models of advanced scanning probe microscope (at left) and biosensor for diagnosis of influenza $A$ virus and E.coli bacteria (at right)

соры для обнаружения вирусов и бактерий // Наноиндустрия. 2016. № 5(67). С. 26-34.

4. Колесов Д., Яминский И., Ахметова А., Синицына О., Мешков Г. Кантилеверные биосенсоры для обнаружения вирусов и бактерий // Наноиндустрия. 2016. № 4 (67). С. 26-35.

5. Киселев Г., Горелкин П., Ерофеев А., Колесов Д., Яминский И. Детекция вирусов с помощью пьезоэлектрических кантилеверов // Наноиндустрия. 2015. № 4 (58). С. 62-67.

6. Ахметова А., Гутник Н., Мешков Г., Синицына О., Яминский И., Назаров И. Биосенсор для обнаружения вирусов и бактерий в жидкостях // Наноиндустрия. 2016. № 8(70). С. 68-73.

7. Соснин В.С., Ахметова А.И., Яминский И.В., Яминский Д.И., Мешков Г.Б., Оленин А.В. Проточная жидкостная ячейка для сканирующей зондовой микроскопии // Заявка на патент. Рег. номер 2016146597 от 29.11.2016.

8. Соснин В.С., Ахметова А.И., Яминский И.В., Яминский Д.И., Мешков Г.Б., Оленин А.В. Проточная жидкостная ячейка для сканирующей зондовой микроскопии // Заявка на патент. Рег. номер 2016146599 от 29.11.2016. 